of our knowledge we should be justified in recommending abstention from parenthood only to those individuals who are affected by hereditary diseases which cause serious damage to vision and in whom the mode of transmission is dominant, to their unaffected blood relatives and to those who may transmit the disease in a sex-linked manner, such as the females in families affected by Leber's optic atrophy. In many other hereditary ocular disorders, although it might seem to some a proper course to advise a potential transmitter to forego parenthood, statistics and facts collected to date afford in many instances a groundwork as yet too insecure for a dogmatic stand to be taken.

In this connexion it is apposite to call attention to the masterly report on Hereditary Diseases of the Eye resulting in Blindness, their social consequences and the measures that may be proposed, which was read at the session of the International Association for the Prevention of Blindness on April 5, by Professor Franceschetti of Geneva.

This is too long for abstraction in this place; it should be read in the original. We append Professor Franceschetti's conclusions.

"In conclusion, we shall briefly summarize the measures discussed in detail in the previous chapters, which we believe will enable us to diminish the incidence of hereditary blindness.

a.-Collection of precise and complete statistics,

$b$.- Training of physicians (especially of ophthalmologists) in genetics, and education of authorities and public,

c.-Extension of facilities for pre-marital consultation, and the general introduction of the pre-marital certificate,

d.-Increased use of social workers,

e.-Decrease in consanguineous marriages,

$f$.-Decrease of the transmission of hereditary eye diseases by making sterilization available to the patients.

I am of the opinion that a committee should be named to study the means of realizing these different objectives. In working upon an international plane, this committee should be able to bring together the material which will permit judgment of the efficacy of the steps taken to decrease hereditary blindness in the various countries, and concrete recommendations to be made in the near future."

\title{
Research Work in Ophthalmology
}

In 1928, Vol. XII, p. 214, we called the attention of our readers to the fact that the management of the Brit. Jl. of Ophthal. was prepared to assist research work in ophthalmology by granting 
subsidies towards the expenses of research work to those qualified to undertake it. As stated at the time the qualifications of the candidate, the proposed subject for research and the place where it is to be undertaken, must be submitted for approval to the Editorial Committee. The applicant should give an estimate of the time and expense necessary for the completion of the research and indicate the extent of the financial assistance required.

The right to publish papers based on the research must be given to this journal. Applications on this subject should be addressed to the Editors.

\section{THE COUNCIL OF BRITISH OPHTHALMOLOGISTS}

\section{Annual Report}

The Council presents its report for the year 1934-35. At its first meeting the following were elected as Officers :-President : Mr. Leslie Paton; Vice-Presidents: Mr. P. H. Adams, Mr. E. Brewerton; Hon. Treasurer: Mr. A. H. Levy; Hon. Secretary : Mr. M. L. Hepburn.

The following were appointed to serve on the Executive Committee :- The President and Secretary (ex-officio) with Messrs. Greeves, Juler, Levy, Neame, Russ-Wood, and Miss Ida Mann. $\mathrm{Mr}$. Juler and $\mathrm{Mr}$. Neame were elected to represent the Council on the Ophthalmic Committee of the British Medical Association.

It is with much regret that the Council has to report the resignation of $\mathrm{Mr}$. Leslie Paton, who felt compelled to give up his position as President. The Council wish to express their sincere thanks for his efforts and guidance during his term of office. Sir John Parsons was unanimously elected President to succeed him.

The Council has to deplore the death of two of their most active members :- Mr. Bernard Cridland and Mr. Stephen Mayou. The latter was the Treasurer to the Council at the time of his death, and did very valuable work on various Sub-Committees connected with many subjects. He also was one of the Council's representatives on the Ophthalmic Committee of the British Medical Association, and his services helped to keep the two bodies closely in touch with each other. Mr. Bernard Cridland's special experience in the industrial diseases of the eye led the Council to entrust to him much work in any investigations on such subjects : and he always gave of his best ungrudgingly in the service of the Council.

During the year the Council has been investigating the question of Orthoptic Training and the status of those who practise or 